\title{
Tumor de células gigantes - evolução histórica do seu diagnóstico e tratamento junto ao Instituto de Ortopedia e Traumatologia da FMUSP*
}

\author{
Giant Cells Tumor - diagnosis and treatment history evolution in Instituto de Ortopedia e \\ Traumatologia from FMUSP *
}

\begin{abstract}
Olavo Pires de Camargo ${ }^{1}$, Alberto Tesconi Crocri, Cláudia Regina Gomes Cardin Mendes de Olineira ${ }^{3}$, André Mathias Baptista4 Marcelo Tadeu Caiero ${ }^{5}$, Marcelo Abrantes Giannotti ${ }^{6}$
\end{abstract}

O tumor de células gigantes (TGC) é uma neoplasia óssea benigna agressiva de comportamento biológico incerto, constituído histologicamente por células gigantes multinucleadas dispersas pelo tecido tumoral, cujo núcleo apresenta as mesmas características das células ovóides e fusiformes que formam o seu estroma.

A graduação anatomopatológica é dada pelo seu estroma e não pelas células gigantes, que podem estar presentes também em outras lesões tumorais e pseudotumorais como o tumor marrom do hiperparatireoidismo, o cisto ósseo aneurismático, o condroblastoma epifisário, o osteoblastoma e o fibroma não osteogênico.

Os aspectos radiográficos clássicos do TGC o definem como uma lesão epifisiometafisária, lítica, insuflativa, excêntrica, com afinamento ou erosão da cortical, em adulto jovem na faixa dos 20 aos 35 anos de idade, localizado mais freqüentemente no fêmur distal e na tíbia proximal, podendo ocorrer em outras patologias, destacando-se pela sua gravidade o osteossarcoma telangectásico e o fibrohistiocitoma ósseo maligno. Dentre as lesões benignas, notadamente o cisto ósseo aneurismático e o condroblastoma epifisário fazem o diagnóstico diferencial com o TGC. Com menor freqüência, pode estar localizado no úmero proximal, rádio distal, fêmur proximal, coluna dorsal e sacro.

Clinicamente, seu comportamento é agressivo (estadiamento B3 de ENNEKING), com crescimento rápido, às vezes em semanas, apesar de oligossintomático, levando ao afinamento e ruptura da cortical óssea, com invasão das partes moles adjacentes, sem entretanto invadir e ulcerar a pele e o tecido celular subcutâneo. A princípio pode ser confundido como uma lesão intrínseca do joelho, principalmente se a radiografia não for atualizada e bem feita, já que alterações nítidas podem ser notadas com intervalo de 10-15 dias. A nossa própria experiência mostra que, em alguns casos encaminhados
Giant Cells Tumor (GCT) is an aggressive benign bone neoplasia, with an uncertain biological behavior. It is histologically constituted of giant multinuclear cells spread over tumoral tissue with a nucleus presenting the same features of the ovoid and fusiform cells forming its stroma.

The anatomopathological rate is given by its stroma and not by the giant cells that can also be present in other tumoral and pseudo-tumoral lesions such as the hyperparatireoidism brown tumor, the aneurismatic bone cyst, the epiphysial condroblastoma, the osteoblastoma and the non-osteogenic fibroma.

Classic radiologic features of GCT: lytic, pumping, eccentric, with thinning or erosion of cortical bone, epiphysial-metaphyseal lesion, found in young adults from 20 to 35 years old, more frequently located in distal femur or proximal tibia, can be found in other pathologies, deserving emphasis for its severity the teleangectasic osteosarcoma and malignant bone fibrohystiocitoma. Among benign lesions, aneurismatic bone cyst and epiphysial condroblastoma are differential diagnosis from GCT. Less frequently it can be located in proximal humerus, distal radius, proximal femur, dorsal spine and sacrum.

It has a clinically aggressive behavior (B3 ENNEKING staging), with a fast growth, sometimes in weeks, however has few symptoms, leading to thinning and rupture of bone cortical, invasion of adjacent soft tissues, but not however invading or ulcerating skin and subcutaneous tissue. Can be misdiagnosed as an intrinsic knee injury especially if radiography is not up to date and well performed, since clear changes can be noticed in a 10 to 15 days interval. Our own experience shows cases sent from very far away not surgically treated which after a period of fast growth stopped evolution and had bone bars formed inside and necrosis areas, but never ulceration.
* Trabalho realizado no Grupo de Oncologia Ortopédica do Instituto de Ortopedia e
Traumatologia do Hospital das Clínicas da Faculdade de Medicina da Universidade de São
Paulo.
1 Professor Livre-Docente e Chefe do Grupo de Oncologia Ortopédica do IOTHCFMUSP.
2 Professor Livre-Docente e Sub-chefe do Grupo de Oncologia Ortopédica do IOTHCFMUSP.
3 Chefe do Serviço de Anatomia Patológica do IOTHCFMUSP.
4 Médico Assistente do Pronto-Socorro e do Grupo de Oncologia Ortopédica do IOTHCFMUSP.
5 Médico Assistente do Pronto-Socorro e do Grupo de Oncologia Ortopédica do IOTHCFMUSP.
6 Médico Assistente do Serviço de Anatomia Patológica do IOTHCFMUSP.
Trabalho recebido em 04/01/2000. Aprovado em 12/06/2001
* This work was performed at the Orthopedic Oncology Group from Instituto de Ortopedia e Traumatologia of Hospital das Clínicas da Faculdade de Medicina da Universidade de São Paulo.

1 Livre-Docente Professor and Chief of Orthopedic Oncology Group from IOTHCFMUSP. 2 Livre-Docente Professor and Sub chief of Orthopedic Oncology Group from IOTHCFMUSP.

3 Chief of Pathologic Anatomy Service from IOTHCFMUSP.
4 Assistant Doctor from Emergency Room and Orthopedic Oncology Group from IOTHCFMUSP. 5 Assistant Doctor from Emergency Room and Orthopedic Oncology Group from IOTHCFMUSP. 6 Assistant Doctor of Pathologic Anatomy Service from IOTHCFMUSP. 
de locais longínquos e que não foram tratados cirurgicamente, houve após certo período de crescimento rápido uma parada de evolução, com formação de traves ósseas no seu interior, além de áreas de necrose, mas nunca ulceração.

Dos 389 casos tratados no Instituto de Ortopedia e Traumatologia do Hospital das Clínicas da FMUSP, no período de 1950 a 1998, só tivemos dois casos que ocorreram abaixo dos 15 anos de idade, com a epífise ainda aberta (TGC estritamente metafisário). Em apenas um paciente houve acometimento de mais de um osso (rádio distal e fíbula proximal) e apenas dois casos foram classificados histologicamente como grau III, ou seja, TGC malignos, que acabaram falecendo por metástase pulmonar um ano após o diagnóstico. Em dois casos ocorreu metástase pulmonar com características histológicas benignas, que tiveram boa evolução clínica, após ressecção da lesão pulmonar, atualmente com mais de 15 anos de seguimento.

As neoplasias ósseas são relativamente raras, correspondendo a $2 \%$ das neoplasias em geral. Os TGC constituem $8 \%$ dos tumores ósseos primários. É freqüente entre os povos asiáticos como na China, onde a incidência corresponde a $20 \%$ dos tumores ósseos.

Histologicamente, sabe-se que foi descrito primeiramente por COOPER em $1818^{(8)}$, sendo considerado uma "exostose medular fúngica". Em 1845, LEBERT ${ }^{(19)}$ descreveu um grupo de tumores ósseos com células gigantes multinucleadas que apresentam tendência a recidivar, mas que foram curados com a amputação.

PAGET, em $1854{ }^{(28)}$, denomina esta lesão como um sarcoma mielóide e faz seu primeiro esboço macroscópico. Em 1860, NELATON ${ }^{27)}$ estuda 46 casos, considerando-os como lesões benignas, sendo entretanto todos os casos amputados. MORRIS em $1876^{(25)}$, KRAUSE (1889) ${ }^{(18)}$ e VOLKMANN (1899) (35) descrevem os primeiros casos tratados com curetagem local, que tiveram boa evolução clínica e funcional.

Foi entretanto BLOODGOOD, em $1912^{(1)}$, que emprega o nome TGC, estabelece suas características clínicas e descreve os resultados de 52 pacientes submetidos à curetagem com o uso de um adjuvante local (ácido carbólico), colocando enxerto ósseo de ilíaco para preencher a cavidade. Foi o primeiro a usar a cauterização química e a considerar o TGC como um tumor benigno agressivo, evitando assim a amputação.

JAFFE et al., em $1940{ }^{(16)}$, estabelecem o TGC como uma entidade clínica e patológica, separando esta lesão das ali então consideradas como variantes: fibroma não osteogênico, condroblastoma epifisário e o osteoblastoma. Seu amplo espectro de comportamento clínico é baseado no grau de atipia de células de seu estroma: Grau I - sem atipia celular, Grau II com algum grau de atipia e Grau III - grande atipia celular, sendo considerado francamente maligno.

DAHLIN et al. (1970) ${ }^{(9)}$ publicam trabalho clássico na Clinica Mayo com $60 \%$ de recidiva local em pacientes com TGC submetidos a curetagem e enxertia, recomendando uma ressecção mais agressiva para seu controle local, como a artrodese tipo "Putti-Juvara" nos casos de tumor ao nível do
From the 389 cases treated at Instituto de Ortopedia e Traumatologia do Hospital das Clínicas da FMUSP, from 1950 to 1998, only two cases were observed under 15 years of age, with a still open epiphyses (strictly metaphyseal GCT). Only one patient had more than one bone committed (distal radius and proximal fibula) and only two cases were histologically graded III or more, that means, malignant GCT who died due to pulmonary metastasis one year after diagnosis. In two cases pulmonary metastasis histologically benign were observed, and had a more than 15 years follow-up good clinical evolution after resection of the pulmonary lesion.

Bone neoplasias are relatively rare, being $2 \%$ of all neoplasias. GCT represents $8 \%$ of all primary bone tumors. It is frequent among Asian people as in China, where it represents $20 \%$ of bone tumors.

Histologically it is known this lesion was first described by COOPER in 1818(8), and considered a "fungal medullar exostosis" In 1845 LEBERT ${ }^{(19)}$ described a group of bone tumors with multinucleated giant cells presenting a trend to recur and healed by amputation.

PAGET in 1854(28) calls this lesion myeloid sarcoma and draws its first macroscopic scheme. In 1860 NELATON(27) studies 46 cases understanding them as benign lesions, being however all cases amputated. MORRIS in 1876 (25), KRAUSE in 1889(18) and VOLKMANN in 1899(35) described the first cases treated by local curettage having good functional and clinical evolution.

However BLOODGOOD(1) in 1912 was the first to use the name GCT, establishing its clinical features and describing the results of 52 patients who underwent curettage and the use of a local adjuvant, carbolic acid, filling the cavity with iliac grafting. He was the first to use chemical cauterization and to understand GTC as an aggressive benign tumor, so avoiding amputation.

JAFFE et al. in 1940(16) established GCT as a clinical and pathological entity, differentiating it from the lesions considered as variants so far: non-osteogenic fibroma, epiphysial condroblastoma and osteoblastoma. Its large spectrum of clinical behavior is based on the degree of atypia of its stroma cells: Grade I - without cellular atypia, Grade II with some degree of atypia and Grade III with much cellular atypia, being considered as frankly malignant.

DAHLIN et al. (1970) ${ }^{(9)}$ published a classical paper from Mayo Clinic with $60 \%$ of local recidivation in patients who underwent curettage and grafting, so recommending a more aggressive resection for local contro/ with an arthrodesis as "Putti-Juvara" in cases of tumors around the knee.

GOLDENBERG in $1970^{(14)}$, reports $55 \%$ of local recidivation in 218 cases of GCT and McCARTHY in 1980(24), describes in 52 patients $45 \%$ while HUTTER et al. in 1940(15) reports $66 \%$ among 72 cases. All these works indicate for GCT segmental resection followed by arthrodesis.

Analyzing GCT cases treated at IOT from 1950 to 1972 it is observed that treatment performed followed the trends of the largest oncologic centers of the time, being at the beginning amputated or even underwent radiotherapy. Later on, in 1960, 
joelho.

GOLDENBERG, em $1970{ }^{(14)}$, refere $55 \%$ de recidiva local

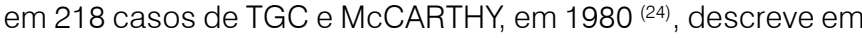
$45 \%$ de recidiva em 52 pacientes, contra HUTTER et al., em $1940{ }^{(15)}$, com $66 \%$ em 72 casos. Todos estes trabalhos passam a indicar uma ressecção segmentar para o TGC, seguida de artrodese.

Ao analisarmos a casuística dos TGC tratados no IOT de 1950 até 1972, iremos observar que a conduta seguiu a tendência dos maiores centros oncológicos da época, sendo que a princípio os casos foram amputados e até submetidos a radioterapia. Posteriormente, em 1960, os casos foram submetidos a curetagem e enxerto ósseo, havendo também um alto índice de recidiva local (48\%). A partir de 1964, a conduta passou a ser então mais agressiva, com ressecção segmentar e artrodese tipo "Putti-Juvara" para os tumores do joelho e endoprótese de acrílico para os casos de fêmur e úmero proximais.

Em 1972, o Professor FLÁVIO PIRES DE CAMARGO, baseado na experiência pessoal de WILTSE et al., de $1957^{(37)}$, passa a empregar pioneiramente o metilmetacrilato associado à cauterização da cavidade como adjuvantes locais no tratamento do TGC, obtendo $9 \%$ de recidiva local nos seus primeiros casos e preservando assim a mobilidade articular. Este trabalho veio a ser publicado com casuística de 135 casos em $1987^{(3)}$ e foi tema da Tese de Livre-Docência do Professor OLAVO PIRES DE CAMARGO (4). Além do cimento, colocavase na época um módulo de polietileno baseado na radiografia da lesão. Em 1984, PERSSON et al. apresentam na Suécia a mesma experiência com 12\% de recidiva local, também com seguimento mínimo de dois anos (29). Seguiram-se outros autores, dentre os quais destaca-se WILLERT, em 1987, com igual sucesso (36)

PERSSON foi o primeiro a publicar no Clinical Orthopedics, em 1976, seus resultados iniciais, tendo inclusive incitado o Professor Flávio que publicasse no mesmo número seus resultados, mas este preferiu aguardar por um seguimento mais longo, antes de fazê-lo. Deste modo, todos os méritos recaíram sobre PERSSON como idealizador deste método. Já WILLERT (1987) (36) preconizava a retirada do cimento dois anos após a cirurgia, por achar que o mesmo pudesse causar problemas futuros à articulação envolvida.

Em 1973, no Memorial de Nova lorque, MARCOVE et al. ${ }^{(23)}$ empregam o nitrogênio líquido como adjuvante para controle local do TGC, conseguindo $5 \%$ apenas de recidiva local, mas tendo como complicação um alto índice de fratura patológica (25\%) conseqüente a este procedimento.

Na Clinica Mayo, em Rochester, ROCK (1980) ${ }^{(32)}$ emprega o fenol associado ao cimento como adjuvante, alcançando resultados semelhantes quanto à recidiva da neoplasia, com poucas complicações.

Apesar destes bons resultados, alguns centros oncológicos ainda viam com reservas uma conduta mais conservadora para patients underwent curettage with bone grafting, also with a high degree of local recidivation (48\%). Starting from 1964 it was started a more aggressive indication, with segmental resection and "Putti-Juvara" arthrodesis for knee tumors and acrylic endoprosthesis for cases of proximal femur and humerus.

In 1972, Professor FLÁVIO PIRES DE CAMARGO, based on personal experience of WILTSE et al. (1957) ${ }^{(37)}$ is the pioneer in using mety-metacrilate along with cavity cauterization as local adjuvants of GCT getting 9\% of recidivation in his first cases, so preserving joint movement. This work was published with 135 cases in $1987^{(3)}$ as Professor OLAVO PIRES DE CAMARGO FreeTeaching Thesis. In addition to methylmethacrylate used a polyethylene module based on the radiography of the lesion. In 1984 PERSSON et al. in Sweden present the same experience with $12 \%$ total recidivation, also with a minimal follow-up of two years ${ }^{(29)}$. Other authors followed among them WILLERT in 1987(36) equally well succeeded.

PERSSON was the first to publish in Clinical Orthopedics in 1976 his initial results, also inciting Professor Flávio to publish his reports in the same issue, but he preferred to wait for a longer follow-up before doing it. All merits went this way to PERSSON as the creator of the method. WILLERT (1987)(36) recommended the removal of the cement two years after the surgery, for understanding that it could cause future problems to the joint.

In 1973, in New York Memorial, MARCOVE et al. (23) used liquid nitrogenium as an adjuvant for local controlling of GCT, getting only $5 \%$ of local recidivation, however with a high incidence of pathological fracture (25\%) as a complication of this method.

At Mayo Clinic in Rochester, ROCK in $1980^{(32)}$ used phenol in association to cement as adjuvant, getting similar results in regard to recidivation of the tumor, with few complications.

Disregarding these good results, some oncological centers still were not confident on a more conservative treatment of GCT, mainly in USA where wide resection and arthrodesis was prevalent, mostly by ENNEKING (1983) who was by that time the most important authority in orthopedic oncology.

There was still fear of malignant transformation of the GCT based on HUTTER et al. (1940)(15) and ELLIS (1949)(11) papers. However, it is today known that or a GCT is primarily malignant, what is rare (4\%), or is transformed due to radiotherapy (COMPERE - 1953)(6).

Some experimental works as that performed by LINDER (1977) ${ }^{(20)}$ prove the local effect of methylmethacrylate that reaches $72^{\circ} \mathrm{C}$ during its polymerization phase, what is enough to destroy the neoplasic cells around inner wall of the cavity, since protein denaturation takes place at $42^{\circ}$ C. MALLAWER et al. in 1987(20) performed an experimental work in rabbits, using liquid nitrogenium and methylmethacrylate showing nitrogenium necrosis to be superior. In 1999 we performed a similar work, comparing acrylic cement, liquid nitrogenium, phenol and 
o TGC, principalmente nos EUA, onde predominava a ressecção ampla e artrodese, principalmente por ENNEKING (1983), que era na época a maior autoridade em oncologia ortopédica ${ }^{(12)}$

Ainda existia o receio de transformação maligna do TGC pelos trabalhos de HUTTER et al. (1940) ${ }^{(15)}$ e ELLIS (1949) (11). Hoje se sabe que o TGC ou é primeiramente maligno, o que é raro (4\%), ou se transforma devido à radioterapia (COMPERE, $\left.1953^{(6)}\right)$.

Alguns trabalhos experimentais, como o realizado por LINDER (1977) (20), comprovam o efeito local do metilmetacrilato, que atinge $72^{\circ} \mathrm{C}$ na sua fase de polimerização, suficiente para destruir as células neoplásicas junto à parede interna da cavidade, já que a temperatura de desnaturação protéica é de $42^{\circ} \mathrm{C}$. MALLAWER et al., em $1987^{(21)}$, realizam trabalho experimental em coelhos empregando o nitrogênio líquido e o metilmetacrilato, mostrando a superioridade do grau de necrose do nitrogênio. Em 1999, realizamos trabalho semelhante comparando o cimento acrílico, o nitrogênio líquido, o fenol e a eletrocauterização em coelhos, obtendo resultados semelhantes com todos estes adjuvantes quanto ao grau de necrose obtido.

Após a visita de ENNEKING ao nosso país em 1984, tivemos oportunidade de mostrar o trabalho pioneiro do Professor Flávio, sendo então convidados a participar do encontro da MSTS (Musculoskeletal Tumor Society) realizado em Orlando em 1987, onde apresentamos os resultados com 12 anos de seguimento, juntamente com PERSSON, WILLERT e CONRAD. Naquela mesa redonda, este procedimento passou a ser consenso nos centros americanos, europeus e asiáticos.

No Instituto Rizzoli, em Bolonha, em 1990 foram avaliados 776 casos de TGC operados, comparando-se o uso de adjuvante contra apenas curetagem e enxerto ósseo. Participamos com 56 casos como únicos representantes da América Latina. Este estudo multicêntrico veio sedimentar de vez o emprego de dois ou mais adjuvantes locais para controle do TGC, já que houve uma diferença de $45 \%$ do não adjuvante contra $17 \%$ com o uso destes ${ }^{(5)}$.

Em trabalho experimental (1986) realizado em nosso Laboratório de Biomecânica, foi comparado o polietileno e o cimento com relação à resistência do material, sendo constatada uma melhor resistência do cimento isolado. Passamos então, a partir desta data, a empregar somente o metilmetacrilato para o revestimento da cavidade, o que tornou este método mais simples e passível de ser realizado em vários centros, sem a necessidade da confecção do polietileno sob medida para cada caso.

Na nossa experiência, achamos que a técnica cirúrgica com ampla abertura da cavidade, permitindo uma curetagem criteriosa, inclusive com broca elétrica, seguida de uma exaustiva revisão local, é fundamental para um bom resultado final, não importando o tipo de adjuvante utilizado. O metilmetacrilato, além de agir como adjuvante, preenche completamente a cavidade tumoral, sem deixar espaço morto, o que certamente é mais um fator para se evitar recidiva. Sua electron-cauterization in rabbits, getting similar degree of necrosis with all these adjuvants.

At ENNEKING's visit to Brazil in 1984, we had the opportunity to show the pioneer work of Professor Flávio, being so invited to take part in the MSTS (Musculoskeletal Tumor Society) meeting, in Orlando (1987), where we presented the results of 12 years follow-up together with PERSSON, WILLERT and CONRAD. At this round table this procedure starts to be a consensus in American, European and Asian Centers.

At Rizzoli Institute in Bologna, in 1990776 operated GCT cases were analyzed, comparing the use of adjuvant to the single curettage and grafting. We participate with 56 cases as the only representatives from Latin America. This multicenter study made even clearer the use of two or more local adjuvants for controlling GCT, since a difference of $45 \%$ of recidivation in non-adjuvant group to $17 \%$ in the adjuvant group was observed(5)

In an experimental work (1986) performed at our Biomechanics Laboratory, it was compared the use of polyethylene and cement in relation to material resistance being found the isolated cement to be more resistant. We so started from this date to use only methylmethacrylate for filling the cavity, and this made the method more simple and feasible in many other centers, without the need of preparing custom-made polyethylene molds for each case.

From our experience we think that it is fundamental to get good results, whatever is re used adjuvant, a wide opening of the cavity, allowing a very careful curettage, including with electric drill, followed by an exhaustive local review. Methylmethacrylate, besides acting as an adjuvant, fills completely the tumoral cavity leaving no dead space, what is certainly one more factor contributing to avoid recidivation. Its mechanical stability, as demonstrated by few cases of pathologic fracture and absence of complications in more than 25 years of follow-up, allows a fearless use of it. When GCT reaches meta-diaphyseal region, we use a "Ender" kind intramedullary rod along with cement or even AO type plates, fixed over the cement (it is possible to perforate and place screws in the cement) allowing a higher mechanical resistance at this transition place, avoiding a pathological fracture.

A reevaluation of GCT cases operated with resection, cauterization plus methylmethacrylate was performed in 1999, aiming check the persistence of the good functional results observed in the first 15 years (1972 to 1985) now with 25 years follow-up. Also incidence of osteoarthrosis was evaluated in this review. It was demonstrated that knee osteoarthrosis incidence was low (12\%) and the patients were oligo-symptomatic, maintaining joint range of movement, being the diagnosis rather radiological than clinical.

Even though these good results in treatment of GCT, its treatment is still far form the ideal. Not all cases are eligible for resection plus curettage and cement. According to radiographic staging as proposed by ENNEKING and CAMPANACCI in 1987 cases are divided in three degrees (Grade I - Well limited 
estabilidade mecânica, demonstrada para poucos casos de fratura patológica e sem complicações após mais de 25 anos de seguimento, permite o seu emprego sem maiores receios. Nos casos em que o TGC atinge a região meta-diafisária temos empregado hastes intramedulares tipo "Ender" junto ao cimento, ou mesmo placas tipo AO fixadas sobre o cimento (é possível se fazer perfurações e colocar parafusos no cimento), proporcionando uma maior resistência mecânica neste local de transição, evitando-se assim uma fratura patológica.

Em 1999, fizemos uma reavaliação dos casos de TGC operados com ressecção, cauterização e colocação de metilmetacrilato visando observar a persistência dos bons resultados funcionais obtidos nos primeiros 15 anos (19721985), já com 25 anos de seguimento. Também a ocorrência de osteoartrose foi pesquisada nestes pacientes. Ficou demonstrado que a incidência de osteoartrose do joelho foi baixa $(12 \%)$, sendo que os pacientes mostraram-se oligossintomáticos, com manutenção da mobilidade articular, sendo mais um diagnóstico radiográfico do que clínico.

Apesar desses bons resultados, o tratamento do TGC está ainda longe do ideal. Nem todos os casos são elegíveis para ressecção por curetagem seguida de cimento. De acordo com o estadiamento radiográfico estabelecido por ENNEKING e CAMPANACCI em 1987, os casos dividem-se em três graus: Grau I - Tumor com bordas bem delimitadas, e corticais íntegras, Grau II - Cortical expandida com bordas bem delimitadas e Grau III - Bordas não delimitadas com invasão de partes moles. Apenas alguns casos classificados como Grau II podem ainda ser operados por este método. Na nossa casuística, são justamente estes casos que apresentam pior resultado funcional pela falta de arcabouço ósseo e comprometimento do osso subcondral.

Assim, nos TGC grau III, onde há destruição excêntrica das paredes do tumor, com comprometimento da cartilagem articular, optamos pela ressecção ampla da lesão (distal do fêmur, proximal da tíbia, proximal do úmero e proximal do fêmur) e substituição por endoprótese, a qual mantém a mobilidade articular, mesmo sendo indivíduos jovens com neoplasia benigna. Somos contrários à indicação de artrodese nesses casos, mesmo sabendo que estes pacientes são candidatos a revisão da endoprótese em 10 a 15 anos. Nos casos do rádio distal, realizamos a ressecção ampla e substituição por fíbula livre na maioria dos casos, sem artrodese da articulação radiocárpica como primeira opção.

O desafio atual no tratamento do TGC reside nos casos localizados na coluna dorsal e no sacro, onde o uso de adjuvante local quase nunca é conseguido. Temos oportunidade de acompanhar estes pacientes juntamente com o Grupo de Coluna do IOT, e as opções cirúrgicas são restritas. A radioterapia é sempre um risco, pois além de ter resposta duvidosa nos TGC, por ser uma neoplasia benigna com poucas atipias celulares, a literatura mostra que no passado foram justamente esses casos que desenvolveram uma degeneração sarcomatosa (HUTTER et al. ${ }^{(15)}$ e ELLIS ${ }^{(11)}$ ). boundaries tumor, and integral cortical, Grade II - Expanded cortical with well limited borders and Grade III - Non limited borders, with soft tissue invasion). Some few cases rated as Grade II could still undergo this method. Our experience demonstrates that exactly these cases are those who have the worst functional results, because lack bone support and commitment of subcondral bone.

So, in Grade III GCT, with eccentric destruction of tumor walls, with articular cartilage commitment, we choose to perform a wide resection of the lesion (distal femur, proximal tibia, proximal humerus, proximal femur) and with endoprosthesis replacement, which keeps articular movement, even being young individuals with a benign tumor. We disagree of arthrodesis indication in these cases, even knowing they are candidates to revision of the prosthesis in 10 to 15 years. In cases of distal radius, we perform a wide resection and replacement by a free fibula, in most of the cases without arthrodesis of radio-carpal joint as a first option.

Current challenge of GCT is in dorsal spine and sacrum locations, where the use of local adjuvant is very seldom possible. We have the opportunity to follow-up these patients together with our colleagues from Spine Group form IOT, and surgical options are restricted. Radiotherapy is always a risk because besides being of doubtful result in GCT, since it is a benign tumor with few cellular atypias, literature shows that exactly these cases were those with sarcomatous degeneration observed in the past (HUTTER et al ${ }^{(15)}$. e ELLIS(11)).

In sacral GCT the problems remains, even though in our experience we used also curettage plus cementation without cauterization with good results using an anterior or posterior approach with a wide exposure of the cavity and direct view of sacral plexus which is preserved. We prefer this treatment to sacrectomy that, when bilateral at S2 level or more proximal, will worsen very much life quality of these patients due to sphincter incontinency and perineal anesthesia.

In regard of surgical treatment, state of the art in GCT treatment had not large changes in the last two years except for new less morbidity local adjuvants such as $\mathrm{H}_{2} \mathrm{O}_{2}$.

In other oncology areas, works like those of RADIG et al(30). and DE SOUZA et al/(10). emphasize the study of genes related to cellular cycle regulation, the so called onco-genes. Among them the most studied are P53, c-myc and $m d m 2$, in addition to the protein Ki67. So, genetic stability, much studied in gastrointestinal neoplasias, is now being studied in GCT through the evaluation of the micro-satellites as in SCHEINER et a/(33) work. Cytogenetic studies performed by BRIDGE et al(2). show GCT characteristic chromosomal changes, especially those related to telomeric regions. However, due to the small number of studied cases there is no consensus regarding its relation to prognosis.

Histo and cytomorphometric techniques (p/oidia evaluation and cell quantification in cellular cycle) are much used in prognosis evaluation of GCT with conflicting results in several papers (FORNASIER et al(13). e MURATA et al(26).). Another very much studied subject in this field is the role of the 
Nos TGC sacrais, o problema persiste, ainda que na nossa experiência tenhamos empregado também a curetagem mais cimentação, sem cauterização, com bons resultados usando via posterior ou anterior, com ampla exposição da cavidade e visualização direta do plexo sacral, que é preservado. Preferimos esta conduta à sacrectomia, que caso seja bilateral à nível de S2 ou mais proximal, irá piorar muito a qualidade de vida destes pacientes por incontinência dos esfíncteres vesical e anal, e anestesia da região perineal.

O estado atual do diagnóstico e tratamento do TGC mantémse nos últimos dois anos sem grandes alterações no que tange a conduta cirúrgica, a não ser o surgimento de novos adjuvantes locais com menor morbidade como a água oxigenada ( $\mathrm{H} 2 \mathrm{O} 2)$.

Nas outras áreas da oncologia, trabalhos como os de RADIG et al. ${ }^{(30)}$ e DE SOUZA et al. ${ }^{(10)}$ têm dado grande ênfase ao estudo de genes relacionados à regulação do ciclo celular, os chamados oncogenes. Dentre eles, os mais estudados são o P53, o c-myc e o mdm2, além da pesquisa da proteína Ki-67. Deste modo, a estabilidade genética, tema bastante abordado em neoplasias do trato gastrointestinal, também vem sendo estudada nos TGC através da avaliação dos micro-satélites, como no trabalho de SCHEINER et al. ${ }^{(33)}$. Os estudos citogenéticos realizados por BRIDGE et al. (2) mostram alterações cromossômicas características dos TGC, principalmente relacionadas às regiões teloméricas. Porém, devido ao pequeno número de casos estudados, não há consenso sobre suas relações com o prognóstico.

As técnicas de histo e citomorfometria (avaliação da ploidia e quantificação de células dentro do ciclo celular) são bastante empregadas na avaliação prognóstica dos TGC, com resultados conflitantes nos diversos artigos (FORNASIER et al. ${ }^{(13)} \mathrm{e}$ MURATA et al. $\left.{ }^{(26)}\right)$. Um outro assunto bastante estudado nesta área é o papel das metaloproteinases (MMP2 e MMP9) na capacidade e no grau de invasibilidade dos tumores, com alguns trabalhos relacionando-as à agressividade e à recidiva local (RAO et al. (31) e SCHOEDEL et al. (34)). As interleucinas moduladoras também vêm sendo estudadas.

Uma nova técnica de estudo é a capacidade de angiogênese tumoral. KABAN ${ }^{(17)}$ relata um caso mostrando a boa evolução de um TGC com terapia antiangiogênica através de interferon alfa-2, estimulando os estudos de quantificação de vasos sangüíneos, bem como a presença de receptores específicos.

O tumor de células gigantes constitui-se assim, pelo exposto, em um tema apaixonante pelos seus desafios quanto ao seu diagnóstico, que deve ser precoce. A conduta cirúrgica deve ser muito bem planejada e individualizada, devido ao caráter imprevisível da neoplasia quanto ao seu prognóstico local. Certamente os estudos citogenéticos abrirão novos caminhos e tornarão o TGC mais previsível quanto ao seu comportamento biológico num futuro próximo. Desta forma, algumas perspectivas mais longínquas da terapia genética farão com que todas as técnicas e táticas cirúrgicas atuais constituam apenas história da medicina. metalloproteases (MMP2 e MMP9) in the capacity and degree of invasion by the tumors, with some papers relating them to aggressivity and local recidivation (RAO et a/(31). e SCHOEDEL et $\mathrm{a}^{(34)}$.). Modulating interleukins are also being studied.

A new study technique is the tumoral angiogenesis capacity. $K A B A N^{(17)}$ reports a case, showing good evolution of a GCT with anti-angiogenesis therapy with interferon alfa-2, stimulating the studies quantifying blood vessels as well as presence of specific receptors.

For the above exposed, giant cells tumor is an exciting subject for its challenges regarding diagnosis, that should be early, for its surgical treatment, that should be very well planned and custom-made and for the uncertainty of the local prognosis of this neoplasia. Certainly cyto-genetic studies will open new ways, making in a near future GCT more previsible in terms of biological behavior. So, some less near future perspectives of gene therapy will lead all current surgical techniques and tactics to be only history of medicine.

\section{REFERÊNCIAS}

1. BLOODGOOD, J.C. (1912) Apud McCARTHY, E. - Giant-cell tumor of bone: a historical perspective. Clin. Orthop., 153: 14-25, 1980.

2. BRIDGE, J.A.; NEFF, J.R.; MOURON, B.J. Giant Cell Tumor of Bone-Chromosomal Analysis of 48 Specimens and Review of the Literature. Cancer Genet Cytogenet, 58: 2-13, 1992.

3. CAMARGO, F.P.; CAMARGO, O.P. Surgical treatment of benign cavitary bone lesions using methylmethacrylate cement and polyethylene prosthesis: experience with 135 cases, in: Enneking, W.F., ed. Limb Sparing Surgery in Musculo-skeletal Oncology. New York, Churchill Livingstone, 1987, p.527.

4. CAMARGO, O.P. Tratamento cirúrgico do tumor de células gigantes através da ressecção marginal e colocação de metilmetacrilato. (Tese de Livre-Docência). Faculdade de Medicina da Universidade de São Paulo, 1994.

5. CAPANNA, R.; FABRI, N.; BETELLI, A. Joint Study EMSOS-MSTS on curettage of giant cell tumor of bone. Chir. Organi Mov., 85, supl1, 1990.

6. COMPERE, E.L. The diagnosis and treatment of giant-cell tumors of bone. J.Bone Jt. Surg., 35A: 822-30, 1953.

7. CONRAD III, E.U.; ENNEKING, W.F.; SPRINGFIELD, D.S. Giant-cell tumor treated with curettage and cementation, in: Enneking, W.F., ed. Limb Sparing Surgery in Musculoskeletal oncology. New York, Churchill Livingstone, 1987. P.516-9.

8. COOPER, A. (1818) Apud McCARTHY, E. - Giant-cell tumor of bone : a historical perspective. Clin. Orthop., 153: 14-25, 1980 
9. DAHLIN, D.C.; CRUPPS, R.E.; JOHNSON, E.W. Giant-cell tumor. A study of 195 cases. Cancer, v.25, p.1061, 1970.

10. DE SOUZA, P.E.; PAIM, J.F.; CARVALHAIS, J.N.; GOMEZ, R.S. Immunohistochemical expression of p53, MDM2, Ki-67 and PCNA in central giant cell granuloma and giant cell tumor. - J Oral Pathol Med, 28:2, 54-8, 1999 Feb

11. ELLIS, F. Treatment of osteoclastoma by radiation. J. Bone Jt. Surg., 31: 268-80, 1949.

12. ENNEKING, W.F. Musculoskeletal tumor surgery. New York, Churchill Livingstone, 1983. P.69-89.

13. FORNASIER, V.L.; PROTZNER, K.; ZHANG, I.; MASON, L. The prognostic significance of histomorphometry and immunohistochemistry in giant cell tumors of bone Hum Pathol , 27: 754-760, 1996

14. GOLDENBERG, R.R.; CAMPBELL, C.J.; BONFIGLIO, M. - Giant-cell tumor of bone: an analysis of two hundred and eighteen cases. J.Bone Jt.Surg., 52: 619-34, 1970.

15. HUTTER, R.V.P.; LICHTENSTEIN, L.; PORTIS, R.B. Giant cell tumor of bone: its pathologic appearance, grading, supposed variants and treatment. Arch. Pathol., 30: 993-1031, 1940.

16. JAFFE, J.L.; LICHTENSTEIN, L.; PORTIS, G.B. Giant-cell tumor of bone: its pathological appearance, grading supposed variants, and treatment. Arch. Pathol., v.30, p.993, 1940

17. KABAN, L.B.; MULLIKEN, J.B.; EZEKOWITZ, R.A.; EBB, D.; SMITH, P.S.; FOLKMAN $J$. Antiangiogenic therapy of a recurrent giant cell tumor of the mandible with interferon alfa-2a [see comments] - Pediatrics, 103:6 Pt 1, 1145-9, 1999 Jun

18. KRAUSE (1889) Apud McCARTHY, E. - Giant-cell tumor of bone: a historical perspective. Clin. Orthop., 153: 14-25, 1980.

19. LEBERT, H. (1845) Apud McCARTHY, E. - Giant-cell tumor of bone: a historical perspective. Clin. Orthop., 153: 14-25, 1980.

20. LINDER, L. Reaction of bone to the acute chemical trauma of bone cement. J. Bone Jt. Surg., 59A: 82-7, 1977

21. MALLAWER, M.M.; MARKS, M.; McCHESNEY, D.; PIASIO, M.; GUNTHEERS, F.; SHNOOKLER, B.M. Effect of cryosurgery and polymethyl methacrylate on a tumor cavity: evaluation of bone necrosis and bone graft incorporation in a dog model, in: Enneking, W.F., ed. Limb Sparing Surgery in Musculoskeletal oncology. New York, Churchill Livingstone, 1987. P.486-98

22. MARCOVE, R.C.; WIES, L.D.; WAGHAIWALA, M.R. et al. Cryosurgery in the treatment of giant cell tumors of bone: a report of 52 consecutive cases. Clin. Orthop., v, 134, p.275, 1978.

23. MARCOVE, R.C.; LYDEN, J.; HUVOS, A.G.; BULLOUGH, P. Giant cell tumors treated by cryosurgery. A report of 25 cases. J. Bone Jt. Surg., 55 A: 1633, 1973.

24. McCARTHY, E.F. Giant cell tumor of bone: a historical perspective. Clin. Orthop., 153: 14-25, 1980

25. MORRIS, (1876) Apud McCARTHY, E. - Giant-cell tumor of bone: a historical perspective. Clin. Orthop., 153: 14-25, 1980

26. MURATA, H.; KUSUZAKI, K.; TAKESHITA, H.; HIRATA, M.; HASHIGUCHI, S.; ASHIHARA, T.; HIRASAWA, Y. Cytofluorometric DNA ploidy analysis in giant cell tumor of bone: histologic and prognostic value. - Cancer Lett, 136:2, 223-9, 1999 Mar

27. NELATON, E. (1860) Apud McCARTHY, E. - Giant-cell tumor of bone: a historical perspective. Clin. Orthop., 153: 14-25, 1980

28. PAGET, J. (1854) Apud McCARTHY, E. - Giant-cell tumor of bone: a historical perspective. Clin. Orthop., 153: 14-25, 1980.

29. PERSSON, B.M.; EKELUND, L.; LOVDAHL, R. et al. Favorable results of acrylic cementation for giant cell tumors. Acta Orthop. Scand., v.55, p.209-14., 1984.

30. RADIG, K.; SCHNEIDER-STOCK, R.; MITTLER, U.; NEUMANN, H.W.; ROESSNER, A. Genetic instability in osteoblastic tumors of the skeletal system - pathol res pract, 194: 669-677,1998

31. RAO. V.H.; SINGH, R.K.; DELIMONT, D.C.; FINNELL, R.H.; BRIDGE, J.A.; NEFF, J.R.; GARVIN, B.P.; PICKERING, D.L.; SANGER, W.G.; BUEHLER, B.A.; SCHAEFER, G.B. Transcriptional regulation of MMP-9 expression in stromal cells of human giant cell tumor of bone by tumor necrosis factor-alpha. - Int J Oncol, 14:2, 291-300, 1999 Feb

32. ROCK, M. Adjuvant management of benigns tumors; basic concepts of phenol and cement use. EMSOS-MSTS Joint study of giant cell tumor of bone. Chir. Organi Mov. 75, supl. 1, 1990.
33. SCHEINER, M.; HEDGES, L.; SCHWARTZ, H.S.; BUTLER, M.G. Lack of microsatellite instability in giant cell tumor of bone. - Cancer Genet Cytogenet, 88:1, 35-8, 1996 May

34. SCHOEDEL, K.E.; GRECO, M.A.; STETLER STEVENSON, W.G.; OHORI, N.P.; GOSWAMI, S.; PRESENT, D.; STEINER, G.C. Expression of metalloproteinases and tissue inhibitors of metalloproteinases in giant cell tumor of bone: an immunohistochemical study with clinical correlation. - Hum Pathol, 27:11, 1144 8, 1996 Nov

35. VOLKMANN (1899) Apud McCARTHY, E. - Giant-cell tumor of bone: a historical perspective. Clin. Orthop., 153: 14-25, 1980.

36. WILLERT, H.G. Clinical results of the temporary acrylic bone cement plug in the treatment of bone tumors: a multicentric study, in: Enneking, W.F., ed. Limb salvage in mnusculoskeletal oncology. New York, Churchill Livingstone, 1987. P.445-58.

37. WILTSE, L.L.; HALL, R.H.L STEVEHJEM. J.C. Experimental studies regarding the possible use of self curing acrylic in orthopaedic surgery. J. Bone Jt. Surg., 39A: 961-72, 1957. 